\title{
Herb yield and essential oil of dill (Anethum graveolens $L$.) at different locations
}

\author{
S. HÄLVÄ', R. HUOPALAHTI ${ }^{2}$, CH. FRANZ ${ }^{3}$ and S. MÄKINEN ${ }^{4}$ \\ ${ }^{\prime}$ Dept. of Horticulture, University of Helsinki, SF-00710 Helsinki, Finland \\ ${ }^{2}$ Dept. of Chemistry and Biochemistry, University of Turku, SF-20500 Turku, Finland \\ ${ }^{3}$ Inst. for Vegetable Growing, Technical University of Munich, 8050 Freising, West Germany \\ present address: \\ Inst. for Botany and Food Science, Linke Bahngasse 11, A-1030 Wien, Austria \\ ${ }^{4}$ Dept. of Nutrition, University of Helsinki, SF-00710 Helsinki, Finland
}

\begin{abstract}
A study on the effect of growing site on the growth of the dill herb at three locations (Helsinki, Sahalahti, Inari) in Finland and at Freising, West Germany, was carried out in 1985. The growing medium was fertilized peat of the same quality at each location. Dill ('Dura') was sown twice, in early spring and $2-3$ weeks later at all growing sites. The herb crop was harvested just when the first flower buds had developed. The later sowings gave significantly larger yields than the earlier ones. The herb yields were largest at the most southern location. The fresh yield was the larger the more rain there was, and the warmer the growing season was.

The significantly highest oil contents were recorded in the herb of the later sowings at Freising and Sahalahti. Otherwise, no differences in the oil content were recorded. The correlation between the oil content and degree days was positive. The total amount of components responsible for the aroma varied between 4.5 and $7.9 \mathrm{mg} / \mathrm{g}$ dry weight. The amount of essential oil and that of a typical aroma compound in dill, 3.6-dimethyl-2,3,3a,4,5,7a-hexahydrobenzofuran, were not significantly affected by the location.
\end{abstract}

Index words: anethofuran, essential oil, dill herb, growing site, 3,6-dimethyl-2,3,3a,4,5,7a-hexahydrobenzofuran

\section{Introduction}

Dill (Anethum graveolens L.) is one of the most important herb plants in the Nordic countries. It is mostly used as a fresh or dried herb. The seed production, on the other hand, is not successful in the north, and thus there is no wider use of seeds for flavouring in Finland.

It has been claimed that in aromatic herbs the odour and taste are the stronger the farther north they grow. The main ecological differences between the latitudes are the tempera- 
ture and the day length (HÄRDH and HÁRDH 1972, Härdh 1975, Franz et al. 1984). Thus the possible differences in the aroma are probably due to these two factors. Besides, according to HuOPALAHTI (1984), the essential oil content in the dill herb is dependent on the degree days, i.e. the sum of daily temperatures $>+5^{\circ} \mathrm{C}$.

The earliest investigations on the effect of growing site on the quality of vegetables in the northern countries have been conducted by Lamprecht (1929) and Dragland (1969). The effect of day length, intensity and composition of light, and temperature on the quality of various vegetable crops, including dill, was studied in the beginning of the 70's in the Nordic countries (HẢrdH et al. 1977, HÄRDH 1978). The highest contents of aroma compounds were reported in dill grown farthest north. The result is supported by HuOpalaHTI (1984). Otherwise the investigations on this subject are few.

Recent studies report partly conflicting results on the effects of growing site. YLiaho (1981) found no clear differences in the total content of essential oil in the roots of angelica (Angelica archangelica L.) grown on similar soils and at different locations in Finland. FrANZ et al. (1984, 1986) investigated the essential oil content of peppermint (Mentha $\times$ piperita L.) and chamomile (Chamomilla recutita (L.) Rauschert) grown at different locations in Europe, the chamomile also in Finland. The oil content of peppermint was not affected by the growing site, and no qualitative changes were found in the oil composition of chamomile grown at different locations. Certain quantitative differences were, however, observed between the northern and southern locations (Franz et al. 1986). Similarly, there were no differences in the essential oil content of different dill varieties due to the locations in Finland (HÄLvä 1987).

The influence of latitude appears to depend on the specific plant species, too. For instance, the formation of essential oil is less dependent on ecological factors in chamomile than in peppermint (FranTZ et al. 1984, 1986).
The aroma characteristics and the fresh herb yield of dill grown in West Germany and at three locations in Finland were investigated in the present study. The purpose was to determine the effect of the southern and northern growing sites (latitude) on the productivity and on the content and composition of the aroma causing compounds (from here on referred to as aroma compounds) in the dill herb.

\section{Material and methods}

The experiment was carried out in 1985 at three locations in Finland, i.e. in Helsinki $\left(60^{\circ} 14^{\prime} \mathrm{N}\right)$, Sahalahti $\left(61^{\circ} 28^{\prime} \mathrm{N}\right)$ and Inari $\left(69^{\circ} 04^{\prime} \mathrm{N}\right)$, and at Freising, West-Germany $\left(48^{\circ} 24^{\prime} \mathrm{N}\right)$. The dill variety was 'Dura' Sv, which had earlier given large yields with high content of essential oil (Huopalahti 1985, HĂLVĂ 1986).

The experiment was carried out in pots ( 5 litre) filled with peat (St 400 A2) which had received basic fertilization of 110-124-176 g NPK/pot. Dill was sown twice, 2-3 weeks apart, 50 seeds per pot in a 10 -fold replication at each location. The first sowing was a typical early sowing in May and the second one took place three weeks later except for Inari, where the dill was first sown in June. The later sowing was carried out after two weeks because of the shorter growing season in the north (Table 1). The plants were exposed to rainfall, and were irrigated during the dry periods. No fertilizers were broadcast.

The height of the plants was measured and the fresh herb yield weighed when harvested, at the first appearance of flower buds. The herb was frozen, and three samples of both sowings at each location were analysed for the content and composition of essential oil. Also the dry weight was determined $\left(+102-106^{\circ}\right.$, $6 \mathrm{~h})$.

Aroma compounds were isolated by extracting for six hours $50 \mathrm{~g}$ (fresh weight) of chopped dill leaves and branches with a mixture of n-pentane and diethyl ether (1: 2, v/v) by using a modified Soxhlet technique, in which 
Table 1. Data on climatic factors during the growing period of dill herb, height of the plants at harvest, and dried yields/pot (5 I). Two sowings (dates) were carried out at four locations in 1985.

\begin{tabular}{lccccccc}
\hline $\begin{array}{l}\text { Location, } \\
\text { sowing } \\
\text { dates }\end{array}$ & $\begin{array}{c}\text { Rainfall } \\
\mathrm{mm}\end{array}$ & $\begin{array}{c}\text { Degree } \\
\text { days } \\
{ }^{\circ} \mathrm{C}\end{array}$ & $\begin{array}{c}\text { Hours of } \\
\text { sunshine }\end{array}$ & $\begin{array}{c}\text { Radiation } \\
\mathrm{MJ} / \mathrm{m}^{2}\end{array}$ & $\begin{array}{c}\text { Growing } \\
\text { period, } \\
\text { days }\end{array}$ & $\begin{array}{c}\text { Height/ } \\
\text { plants } \\
\mathrm{cm}\end{array}$ & $\begin{array}{c}\text { Dried } \\
\text { yield/ } \\
\text { pot, g }\end{array}$ \\
\hline $\begin{array}{l}\text { Freising } \\
\text { May 3. }\end{array}$ & 228 & 426 & 302 & 819 & 48 & 46 & 30.5 \\
$\quad$ May 24. & 134 & 464 & 314 & 852 & 48 & 46 & 40.7 \\
$\begin{array}{l}\text { Helsinki } \\
\text { May 24. }\end{array}$ & 195 & 416 & 342 & 757 & 46 & 25 & 14.8 \\
$\quad$ June 14. & 191 & 467 & 250 & 590 & 41 & 30 & 21.5 \\
$\begin{array}{l}\text { Sahalahti } \\
\text { May 22. }\end{array}$ & 184 & 424 & 287 & 724 & 49 & 35 & 17.3 \\
June 12. & 204 & 467 & 263 & 600 & 43 & 43 & 18.2 \\
$\begin{array}{l}\text { Inari } \\
\text { June 17. }\end{array}$ & & & & & & & \\
July 8. & 73 & 391 & 421 & 714 & 49 & 22 & 10.3 \\
\hline
\end{tabular}

the side tube of the regular apparatus was replaced by a column containing glass beads to prevent the cycling of compounds. The extract was concentrated in a Widmer column, to a volume of $2 \mathrm{ml}$. A previous study showed that the extraction used in this investigation was suitable for comparative serial analysis of essential oil compounds (HUOPALAHTI et al. 1981).

The quantitative gas chromatographic analysis was performed on a Varian 3700 gas chromatograph equipped with a flame ionization detector connected to a Hewlett Packard 3388A integrator. A fused silica capillary column $(0.32 \mathrm{~mm}$ i.d. $\times 25 \mathrm{~m}$; film thickness $0.20 \mu \mathrm{m}$ ) coated with OV-351 was used for the separations. The oven temperature was programmed from 70 to $240^{\circ} \mathrm{C}$ after an isothermal period of $2 \mathrm{~min}$. The temperature of the injection port was $245^{\circ} \mathrm{C}$, that of the detector $255^{\circ} \mathrm{C}$. The split ratio was 1: 30 , and the flow rate of carrier gas (helium) was $1.5 \mathrm{ml} / \mathrm{min}$.

The quantitative estimation of individual components was performed using linalool as internal standard. The identification of compounds was carried out using a $70 \mathrm{eV}$ VG Analytical $7070 \mathrm{E}$ mass spectrometer. The isolation and identification methods are discussed in detail in previous papers (Huopa- lahti 1984, 1985, 1986, Huopalahti et al. 1981, Huopalahti and LinKo 1983).

For statistical analysis of results the analysis of variance was applied. The means were tested by the Duncan, Student-Neuman-Keuls or Tukey tests (Steel and Torrie 1980). The correlations of the herb yield and essential oil content were tested between different climatic factors, i.e. rainfall (including irrigation), degree days, hours of sunshine and radiation.

\section{Results and discussion}

\section{Herb yield}

It took $41-57$ days for the crop to grow from sowing until the appearance of the first flower buds (Table 1). The rate of development was highest at the most southern location in Finland, especially when sown in June, at the time the days were longest. This was observed also earlier (Hä̀vä 1987).

In the most southern location, at Freising, the rate of development was consistently 48 days. In the north, in Inari, the crop developed slowly when sown as late as in July. The decrease in radiation and increase in rainfall most probably decreased the rate of development.

The fresh herb yields per pot ranged from 

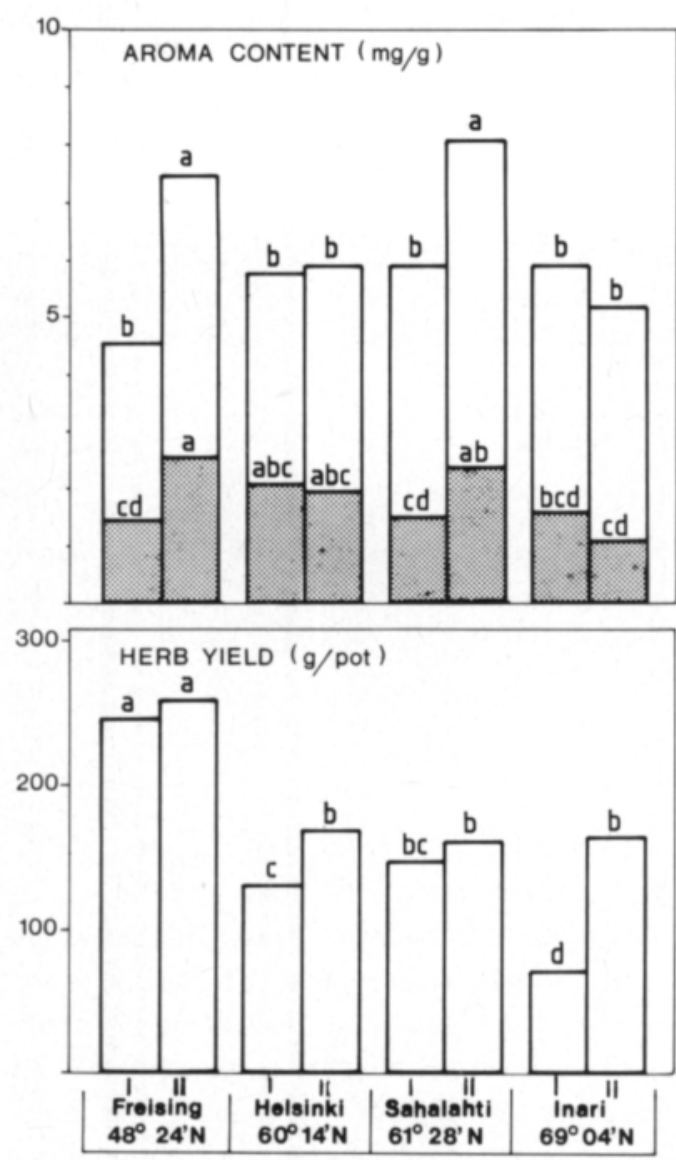

Fig. 1. Fresh yield [Tukey $0.01(8,63)=26.56 \mathrm{~g}$ ], total aroma content [Tukey $0.05(7,14)=1.55 \mathrm{mg} / \mathrm{g}$ ], and proportion of anethofuran (stippled area) in total aroma of dill herb. The two sowings (1 and II) were carried out at four locations in 1985. The bars within the item indicated by the same letters (a-d) belong to the same group of significance.

74 to 261 grams. At the time of harvest there were 39 plants/pot in average. The latter of the two sowings yielded significantly (Freising and Sahalahti: $\mathrm{p}<0.05$, Helsinki and Inari: $\mathrm{p}<0.01)$ larger yields $(191 \mathrm{~g} /$ pot in average) than the earlier one (151 g/pot) (Fig. 1).

The yield was smallest in the first harvest at the location furthest north, and largest in both harvests at the location furthest south, in Germany. The yields correlated positively with the height of the crop (Table 1). Dill yielded equal amounts at the locations in Finland when sown in June in the south, and in July in the north. On the contrary, the smaller yields of the early sowing in the north compared to the south resemble those reported earlier for the early crop (HÄLVÄ 1987). The crop was decreased by the cool weather in the north, where the number of degree days remained under $400^{\circ}$.

The number of degree days in the north was significantly $(\mathrm{p}<0.05)$ lower than that in the southern locations (Duncan $(2,4)=12.3^{\circ} \mathrm{C}$ ) and, on the other hand, during the later growing period it was significantly $(\mathrm{p}<0.05)$ greater than during the earlier growing period (Duncan $\left.(2,3)=8.7^{\circ} \mathrm{C}\right)$ (Table 1).

The coefficient of determination $\left(\mathrm{r}^{2}\right)$ of the fresh herb yield and climatic factors (rainfall, degree days, radiation and hours of sunshine) was $85.5 \%$ (Table 1). The separate correlation coefficients (r) were $0.76+++$, $0.58+++, 0.36++$, and $-0.35++$, respectively. The positive correlation between the herb yield and rainfall was strongest.

The proportion of dried yield of the total fresh herb ranged from 9.5 to $15.6 \%$, the highest figures being recorded in the south, at Freising. The dry weight showed significant positive correlations between radiation $(r=$ $0.66+++)$ and the hours of sunshine ( $\mathrm{r}=$ $0.52++)$. The radiation explains $\left(\mathrm{r}^{2}\right) 85 \%$ of the variation. According to HärdH et al. (1977), also the dry matter content of herbs is highest in the south.

\section{Essential oil}

2.1. The content and composition of oil

The total content of aroma components in

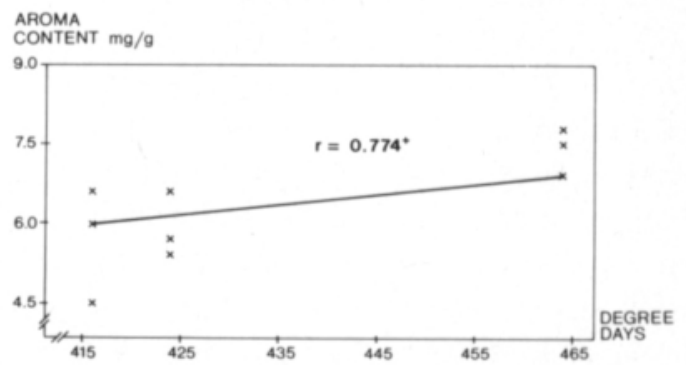

Fig. 2. Correlation between the total aroma content and degree days $\left({ }^{\circ} \mathrm{C}\right)$. 


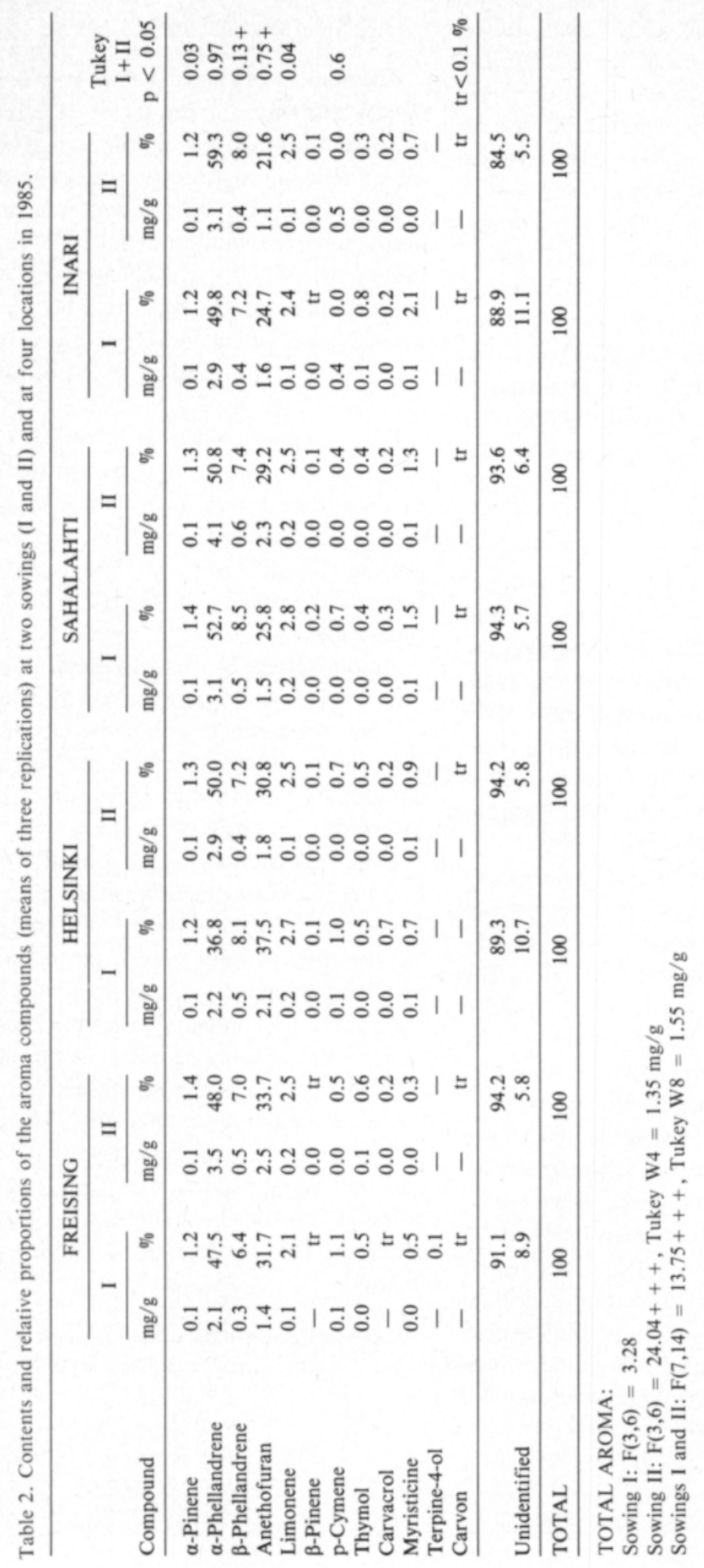


the dill herb ranged from 4.5 to $7.9 \mathrm{mg} / \mathrm{g}$ dry weight (Fig. 1). The highest figures were recorded at Freising and Sahalahti in the herb of the later sowing. Otherwise no differences were found in the total aroma content between the locations. This conflicts with the results reported by HuOPALAHTI (1984) who states $2-3$ fold content for dill grown in the north. However, there was an apparent discrepancy in his results between the years. On the other hand, similar results were recorded when different dill varieties were grown in southern and northern Finland (HÃLvÃ 1987). The results are in agreement also with those on the other essential oil bearing plants (YLIAHO 1981, Franz et al. 1984, 1986).

The essential oil of the herb consisted mainly of five compounds: $\alpha$-phellandrene, limonene, $\beta$-phellandrene, $\alpha$-pinene and 3,6-dimethyl-2,3,3a,4,5,7a- hexahydrobenzofuran (from here on referred to as anethofuran). These compounds formed more than $85 \%$ of the total oil. The main compound was $\alpha$-phellandrene with the content of $37-$ $59 \%$. The content of anethofuran ranged from 22 to $38 \%$ (Table 2).

The contents of the major compounds varied between the locations. The contents of $\beta$-phellandrene and limonene were significantly $(\mathrm{p}<0.05)$ highest at Sahalahti. The content of anethofuran was lowest $(\mathrm{p}<0.05)$ in the later sowing in Inari (Table 2). The amounts of the compounds were, however, not consistently affected by the latitude.

The compounds analysed in this study have been reported also earlier in the dill herb oil (CHOU et al. 1978, Gö́KERITZ et al. 1979, Schreier et al. 1981, Huopalahti et al. 1981, Huopalahti and Linko 1983, Huopalahti 1984, 1985, 1986). Of all the compounds identified, anethofuran is, due to its high aroma value, the character impact compound, which is responsible for the sensory properties in dill herb (Huopalahti 1986).

\subsection{The effect of climatic factors}

The number of degree days proved to be the most important climatic factor affecting the essential oil content of the dill herb. The total oil content increased with increasing degree days (Fig. 2). The correlation was positive between degree days and content of anethofuran $(r=0.427+), \alpha$-phellandrene $(0.491+)$ and limonene $(0.444+)$, too. This conflicts with the statement of Huopalahti (1984) who observed the opposite in the oil content in the dill herb.

Positive correlations were recorded between radiation and contents of p-cymene $(0.454+)$, and sunshine hours and thymol $(0.520+)$. These components are, however, of minor importance in dill herb oil. The correlations between the other climatic factors were not significant.

Among several factors, also the amount and timing of irrigation has proved to affect the oil content of essential oil plants. In this case the timing and comparative studies on the amount of rainfall and irrigation were not determined, though.

The results support sowing of dill in early summer when the degree days are increasing. The larger herb yields will, simultaneously, increase the oil yield even if the oil content remained constant.

It would be necessary to extend the study over several growing periods to determine the constant effects of separate climatic factors on the oil content in aromatic plants. There is an apparent discrepancy between the results of different investigations. The plants should be grown in controlled conditions, e.g. in growth chambers for the detailed study on certain factors.

Acknowledgements. The work was supported by the Finnish Food Industries' Federation and the TIURA foundation. 


\section{References}

Chou, J.S.T., Iwamura, J.I. 1978. Studies of an unknown terpenoid contained in dill weed oil, extract of Anethum graveolens L. from USA and on the analyses of some other dill oils. T'ai-wan K'o Hsueh 32: $131-148$.

Dragland, S. 1969. Vitamin C-inneholdet i hodekal og kalrol dyrket i Nord- og Sör-Norge. Meld. Norg. Landbr. Höjsk. 48: 1-11.

Franz, CH., Ceylan, A., Holzl, J. \& Vomel, A. 1984. Influence of the growing site on the quality of Menthapiperita L.-oil. Acta Hort. 144: 145-150.

Franz, CH., Hardh, K., Hălvã, S., Muller, E., PelzMann, H. \& Ceylan, A. 1986. Influence of ecological factors on yield and essential oil of chamomile ( $\mathrm{Cha}$ momilla recutita (L.) Rauschert syn. Matricaria chamomilla L.). Acta Hort. 188: 157-162.

Góckeritz, D., Poggendorf, A., Schmidt, W. \& SchuBERT, D. 1979. Pohloudek-Fabini, R. Zum Nachweis von 3,6-Dimethyl-2,3,3a,4,5,7a-hexahydrobenzofuran im äterischen öl des Dillkrautes. Pharmazie, 34: $846-847$.

HäLVÃ, S. 1987. Yield and aroma of dill varieties (Anethum graveolens L.) in Finland. Acta Agric. Scand. 37: 329-334.

HÄrd, J.E. 1975. Der Einfluss der Umwelt nördlicher Breitengrade auf die Qualităt der Gemüse. Qual. Plant. 25: $43-56$.

HÁrdh, J.E. 1978. The aromatic compounds of spice plants in Nordic environment. Acta Hort. 73: 269-271.

HÁrdh, J.E. \& HÄdh, K. 1972. Effects of radiation, day-length and temperature on plant growth and quality: a preliminary report. Hort. Res. 12: 25-56.

Hardh, J.E., Persson, A.R. \& Ottosson, L. 1977. Quality of vegetables cultivated at different latitudes in Scandinavia. Acta Agric. Scand. 27: 81-96.

\section{SELOSTUS}

\section{Kasvupaikan vaikutus tillisatoon ja sen haihtuvaan öljyyn}

\section{S. Hälvä ${ }^{1}$, R. Huopalahti ${ }^{2}, \mathrm{CH}$. Franz ${ }^{3}$ and} S. Mäkinen ${ }^{4}$

\footnotetext{
' Helsingin yliopisto, puutarhatieteen laitos, $00710 \mathrm{Helsinki}$

2 Turun yliopisto, kemian ja biokemian laitos, 20500 Turku

3 3) Inst. for Vegetable Growing, Technical University of Munich, 8050 Freising, West Germany
}

Huopalahti, R. 1984. Effect of latitude on the composition and content of aroma compounds in dill, Anethum graveolens L. Lebensm. -Wiss. u. -Technol. 17: 16-19.

Huopalahti, R. 1985. The content and composition of aroma compounds in three different cultivars of dill. Anethum graveolens. Z. Lebensm. Unters. Forsch. 181: 92-96.

Huорацанті, R. 1986. Gas chromatographic and sensory analyses in the evaluation of aroma of dill herb, Anethum graveolens L., Lebensm. -Wiss. u. -Technol. 19: $27-30$.

Huopalahti, R., Kallio, H., Kärppã, P. \& Linko, R. 1981. Comparison of two isolation procedures for aroma compounds of dill. Flavor '81. Schreier, P. (Ed.). pp. 369-376. Berlin.

Huopalahtı, R. \& Linko, R.R. 1983. Composition and content of aroma compounds in dill, Anethum graveolens L., at three different growth stages. J. Agric. Food Chem. 31: 331-333.

LAMPRECHT, H. 1929. Några köksväxtsorters reaktion mot olika klimatförhållanden. Nordisk Jordbruksforskning. 11, 4: 169-176.

Schereier, P., Drawert, F. \& Heinze, I. 1981. The quantitative composition of natural and technologically changed aromas of plants. VIII Volatile constituents of fresh dill herb, Anethum graveolens L. (Umbelliferae). Lebensm. -Wiss. u. -Technol. 14: 150-152.

Steel, R.G.D. \& Torrie, J.H. 1980. Principles and procedures of statistics, a biometrical approach. $633 \mathrm{p}$. New York.

Yцано, H. 1981. Väinönputken aromiaineista. Luonnon tutkija. 85: 144-146.

Ms received December 24, 1987 present address:

Inst. for Botany and Food Science, Linke Bahngasse 11, A-1030 Wien, Austria

4 Helsingin yliopisto, ravitsemustieteen laitos, $00710 \mathrm{Helsinki}$ 
Tilli on tärkeă Suomessa viljelty yrttimauste, jota kăytetảăn tuoreena ja kuivattuna koti- ja suurtalouksien lisăksi elintarviketeollisuudessa. Keski- ja Etelä-Euroopassa tilliä viljelläăn lähinnä sen siementen takia.

Vuonna 1985 tehdyissă astiakokeissa selvitettiin kasvupaikan sijainnin vaikutusta tillisadon määrään, sekä öljyn maaăräăn ja koostumukseen kolmella paikkakunnalla Suomessa ja Freisingissa, Länsi-Saksassa. Suomen koepaikat olivat Helsinki, Sahalahti ja Inari.

Tilli kylvettiin kaksi kertaa, aikaisin keväăllä ja 2-3 viikkoa myöhemmin samanlaiselle turvealustalle kullakin koepaikalla. Sato korjattiin juuri ensimmäisten kukkanuppujen kehittyessä. Haihtuvan öljyn mäărä ja koos- tumus analysoitiin kaasukromatografi-massaspektrometrian avulla.

Myöhäinen kylvő tuotti suurimman tillisadon. Haihtuvan öljyn maaără oli suurin eteläisimmällä koepaikalla Freisingissa ja Sahalahdella. Yrttisadon ja sademäărăn vălillă oli selvin positiivinen korrelaatio. Eniten sato saatiin eteläisimmällă ja vähiten pohjoisimmalla paikkakunnalla. Öljypitoisuus lisääntyi tehoisan lämpötilan summan lisäăntyessä. Myös lehtitillin öljyn tărkeimmän yhdisteen, anethofuraanin ja tehoisan lămpötilan summan vălillă oli positiivinen korrelaatio. Viljelypaikan maantieteellinen sijainti (pohjoinen-etelä) ei vaikuttanut johdonmukaisesti tillisadon eikả haihtuvan öljyn mảärăăn. 